\title{
RURAL WASTE MANAGEMENT: CHALLENGES AND ISSUES IN ROMANIA
}

\section{Liviu Apostol $^{1}$, Florin-Constantin Mihai $^{2}$}

Keywords: rural areas, dumpsites, EU acquis, sanitation services.

\begin{abstract}
Rural areas of the new EU Member States face serious problems in compliance of EU regulation on waste management. Firstly, the share of rural population is higher and it has lower living standards and secondly, the waste collection services are poorly-developed covering some rural regions. In this context, open dumping is used as an appropriate waste disposal solution generating complex pollution. This paper analyzes the disparities between Romanian counties regarding the rural population access to waste collection services in 2008 which reflects the geographical distribution of rural dumpsites in 2009. It examines on one hand, the role of waste management services to reduce illegal dumping and on the other hand, the dysfunctions of traditional waste management system from rural areas and their implications on local environment.
\end{abstract}

\section{Introduction}

Closure and rehabilitation of open dumps from rural ares has forced local authorities to provide waste collection facilities and to dispose these wastes in urban landfills (Apostol and Mihai,2011). In the context of a majority of population without access to sanitation services, various geographical conditions of the Romanian counties influence the distribution of rural dumpsites parameters (surfaces and/or volumes) . In Romania, it is planned to build a regional sanitary landfill in each county and several transfer stations to serve the urban and rural areas. The current waste management systems must introduce selective collection and to improve waste management facilities.

The share of rural population (44.9\% or 9,656,357 people in 2008) is higher compared with EU-15, and this sector of public utilities from rural areas should become a priority for environmental policies in these circumstances.

The EU and the Government have financially supported several projects for the implementation of integrated solid waste management systems usually for cities

\footnotetext{
1 Prof.Ph.D.”Alexandru Ioan Cuza” University, apostolliv@yahoo.com

2 Ph.D. stud.”Alexandru Ioan Cuza” University, mihai.florin86@yahoo.com
} 
to mitigate de disparities compared to other EU members (Mihai and Apostol,2012).

\section{Materials and methods}

A database was created at Romanian counties level regarding on the one hand, the share of rural population with access to waste collection services in 2008 and on the other hand, concerning the open dumps of the rural areas, based on information provided by the 8 Regional Environmental Protection Agencies and complemented by regional and county waste management plans.

Statistical data (number, area,volume) of rural dumpsites inventoried in 2009 (July 16 being the deadline for closure and rehabilitation) were analyzed in correlation with the population access to sanitation services in 2008, using the method of proportional circles and color range. There are no available data concerning rural dumpsites from Maramure and Sălaj counties. Also, regional statistics may include data on dumpsites for communes declared towns (20042007) being subject to the same environmental regulations. Data accuracy depends on the reports made by local authorities and field inspections conducted by representatives of the National Environmental Guard. It is necessary to perform a geographical analysis at multiscale level such as counties, cities and communes for a proper assessment of waste management plans. Unfortunately, the lack of data and the rudimentary waste management systems from rural areas slow down such an approach. There are also very few single-country case studies using data at regional, provincial or municipal level in the literature (Manzzati and Zoboli, 2008). Passarini et al., (2011) showed that the varied geographical conditions in the Emilia Romagna region of Italy influence the performances of generation and waste collection. The databases of various geographic areas may reveal a pattern of per capita waste indicators. (Chowdhury, 2009)

\section{Results and discussion}

A majority of Romania's population lives in rural areas and poor waste management facilities led to waste dumping on bank of rivers, former quarries or roadsides, polluting environment and damaging the landscape.

In 2008, eight Romanian counties did not provide waste collection services in rural areas and in other 6 counties, the share of rural population with access to these services was very low $(<10 \%)$. Lack of sanitation services and poor waste management facilities have increased the amounts of waste disposed in open dumps. Counties of North-East, South-East and South of Romania have the lowest percentage of rural population served by sanitation services (fig.1) except for Ilfov (over 77\%), Suceava and Prahova counties (over $40 \%$ ), these counties being the most vulnerable to waste pollution (tab.1). 


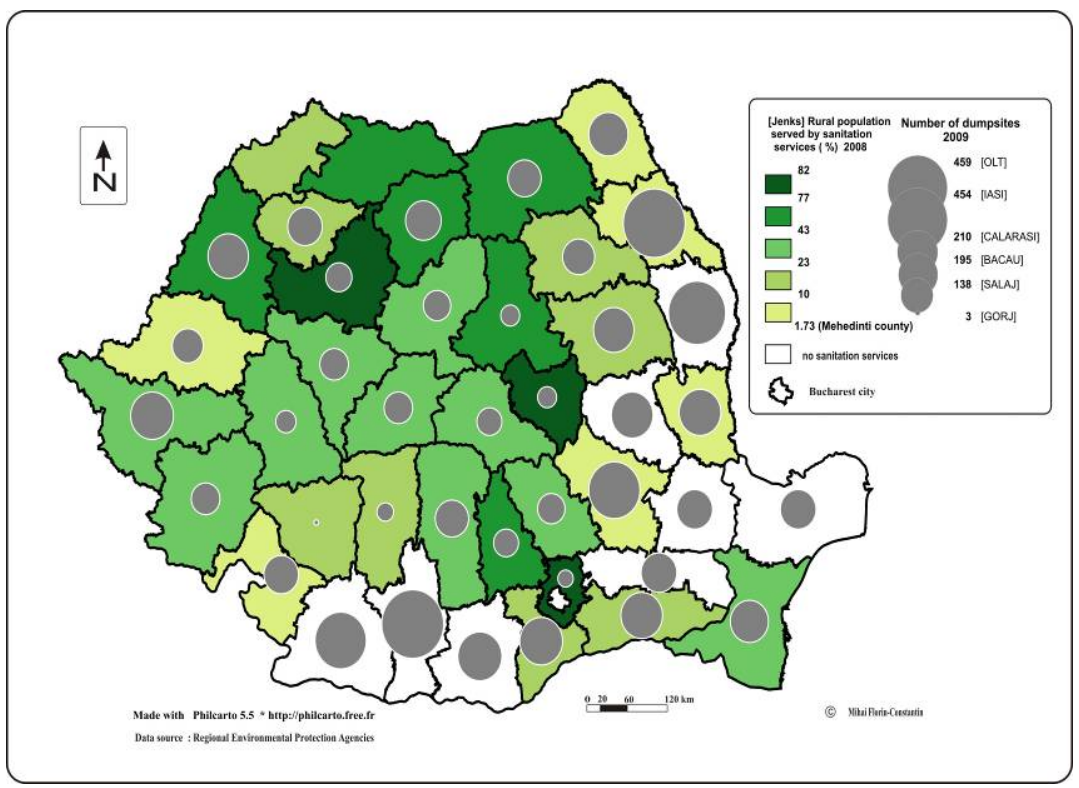

Fig. 1 - Geographical distribution of rural dumpsites numbers/county) in 2009

Tab.1 - Status of rural dumpsites in counties without waste collection services ( 2008)

\begin{tabular}{|l|l|l|l|}
\hline \multirow{2}{*}{ County } & \multicolumn{3}{|l|}{ Rural landfills - closure deadline July 16, 2009 } \\
\cline { 2 - 4 } & Number & Surface (ha) & Volume $\left(\mathrm{m}^{3}\right)$ \\
\hline Dolj & 309 & 228.35 & 516917 \\
\hline Olt & 459 & 87.43 & 213968 \\
\hline Teleorman & 236 & 92.7 & - \\
\hline Ialomita & 151 & 162.8 & - \\
\hline Braila & 154 & 134.29 & 814631 \\
\hline Tulcea & 155 & 97.36 & 75000 \\
\hline Vrancea & 209 & 60.82 & 321737 \\
\hline Vaslui & 389 & 43.98 & 379940 \\
\hline Total & 2213 & 907.73 & $2331923^{*}$ \\
\hline
\end{tabular}

Data source: Regional Environmental Protection Agencies (*incomplete data)

In these regions, the share of rural population is over $50 \%$ in most counties with a few exceptions such as Brăila, Constanța, Galați and Dolj (Nancu et al., 2011) concentrating the largest population of the country. 
This explains the large number of rural dumpsites compared with the center and west of the country where on the one hand the share of rural population is smaller and on the other hand the access to sanitation services is higher (Braşov, Sibiu, Hunedoara) or very high such as Cluj.

The low populated regions compared to other counties, mostly concentrated in depressions,it has facilitated the increase of the population served by sanitation services in the counties of Harghita and Covasna reflecting the smaller number of dumpsites counted in 2009. On the other side, sparsely populated counties with poor sanitation services in rural areas reported a larger number of dumpsites.

The quality of reported data is questionable depending on the responsibility of local authorities. Despite having a lower share of rural population served by services, some counties reported a low number of landfills (Gorj, Vâlcea).

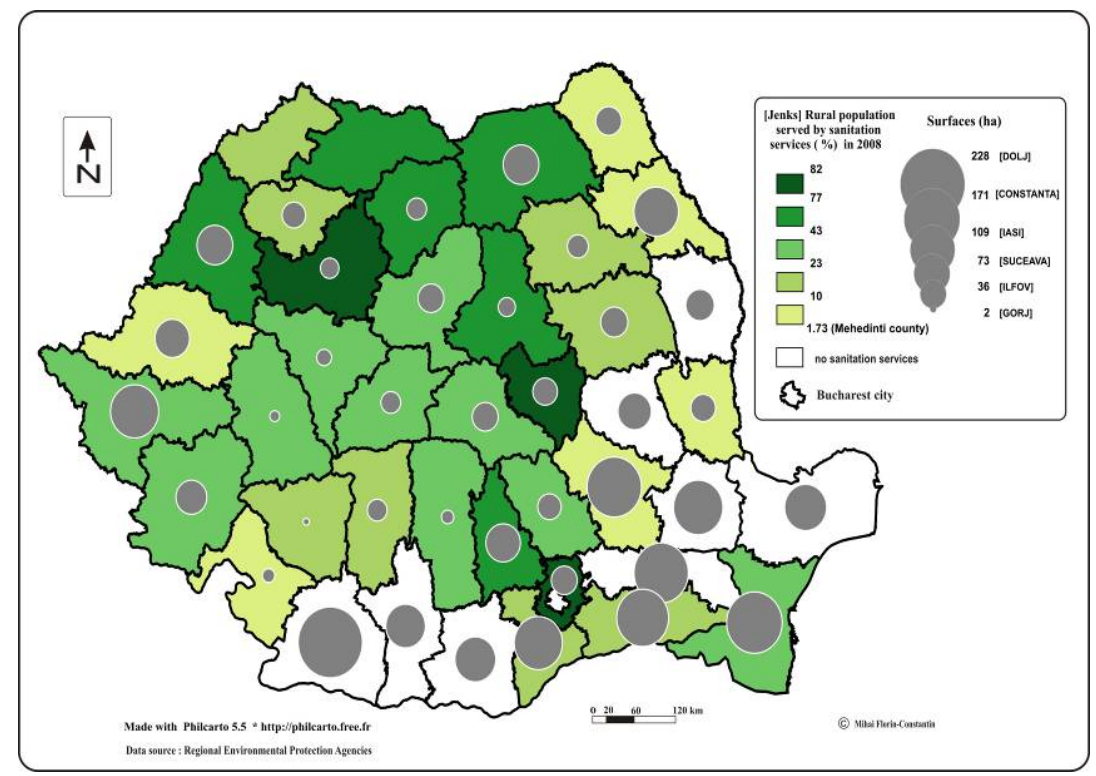

Fig. 2 - Geographical distribution of landfills surfaces of the rural areas (ha) at county level

The plateau and plain regions located in north-east and southern Romania allow a higher rural population density, which led to increasing amounts of waste landfilled than in the central region or in the counties with varied geographical conditions (Neamț, Bacău, Vâlcea, Argeş) reflecting the larger surfaces of dumpsites counted in 2009. However, the lack of sanitation services from rural areas in the plain regions, often leads to waste disposal on the same sites over 
several years, so even in sparsely populated counties, the number and surfaces of these landfills are higher (Brăila, Tulcea, Ialomița, Călăraşi, Giurgiu, Timiş).

Besides the demographic factors, the various geographical conditions of counties influence the number and areas of rural dumpsites in the context of limited access to waste collection services (Mihai et al.,2012)

Thus, in the mountain and hill regions, the expansion of networks of human settlements along the valleys leads to uncontrolled waste disposal on rivers and streams banks; these dumpsites are often flooded. Human settlements developed along floodplains of major rivers in subcarpathian, plateau or plain regions lead to waste disposal over several years on the same sites which have larger surfaces being vulnerable to stronger floods.

Larger open dumps are frequently found in the proximity of human settlements located in regions with a low risk of flooding (plateau areas, interfluvial hills and fluvial terraces) or in the plains, where rural population density is higher and human settlements are more bundled in the absence of geographical constraints. Such rural dumpsites are more extensive and frequent in well populated counties with a significant proportion of rural population and limited access to waste collection services $(<10 \%)$, where plains and low hills dominate the landscape. This is evidenced also by a comparative analysis between the number of rural dumpsites and their occupied areas (fig.3).

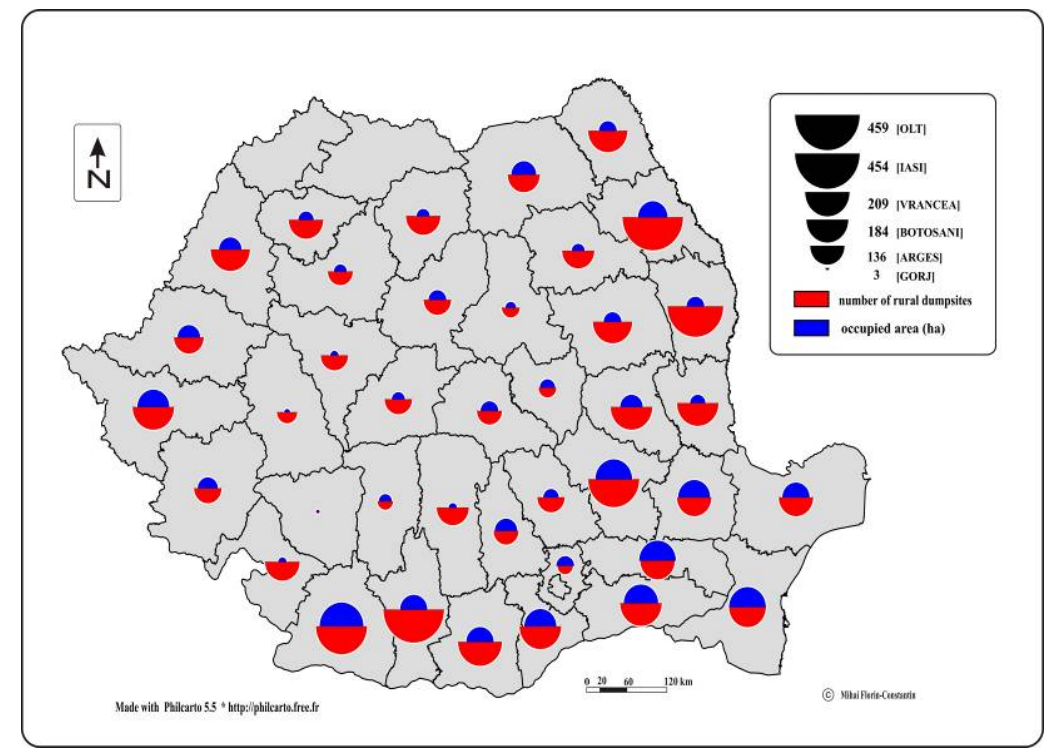

Fig. 3 - Comparative analysis between the number and area occupied by rural landfills 


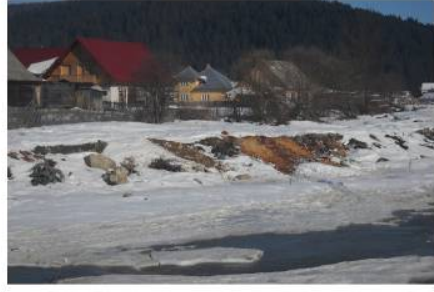

Waste dumping on Putna riverbank, Suceava County,Feb.2010

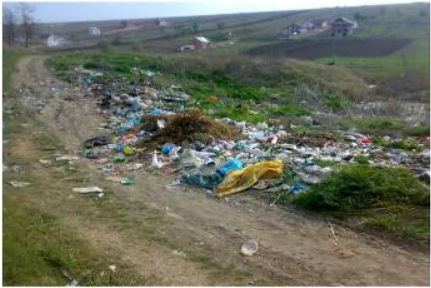

Open dump, Rediu commune, Iasi County, April 2009

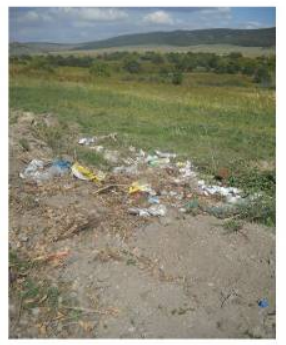

Waste dumping on local roadside, Greci village Tulcea County, Sept. 2009

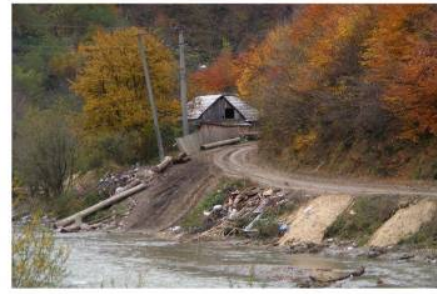

Waste dumping on Vaser riverbank, Maramures County, Nov. 2010

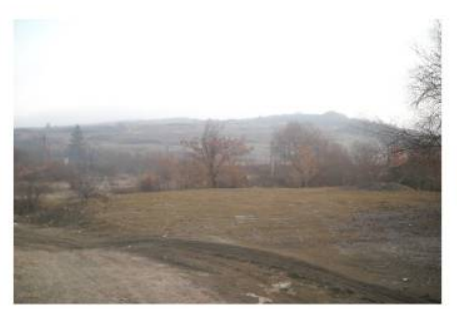

Closed rural dumpsite,Mureni village, Vânători commune, Mureș County, Dec. 2011

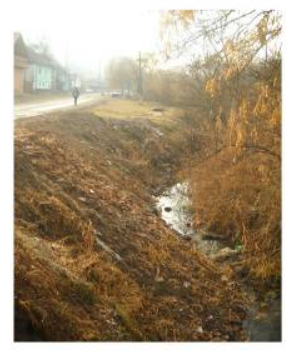

Illegal dumping of waste on stream bank, Bunești village.Braşov county,dec.2011

Fig. 4 - Bad practices in rural waste management (field observations)

In the plain regions, specific for counties outside the Carpathian arch, the number and areas occupied by rural dumpsites are much higher than for the interior counties (Transylvania). Furthermore, in hilly and mountainous counties (Neamț, Bacău, Năsăud, Argeş, Alba) or plateau regions (Botosani, Iaşi, Vaslui), it is noted a large number of dumpsites which cover a lower total surface. Besides, the lowincome of these rural regions may reflect the lower consumption patterns.

The data regarding dumpsites volumes are estimates supervised by county environmental agencies in partnership with local authorities and the quality of 
these data may differ from one county to another, as there is no clear methodology for estimating the volumes of these dumpsites. Thus, the quality of data depends on the reliability of reports made by the rural communities.

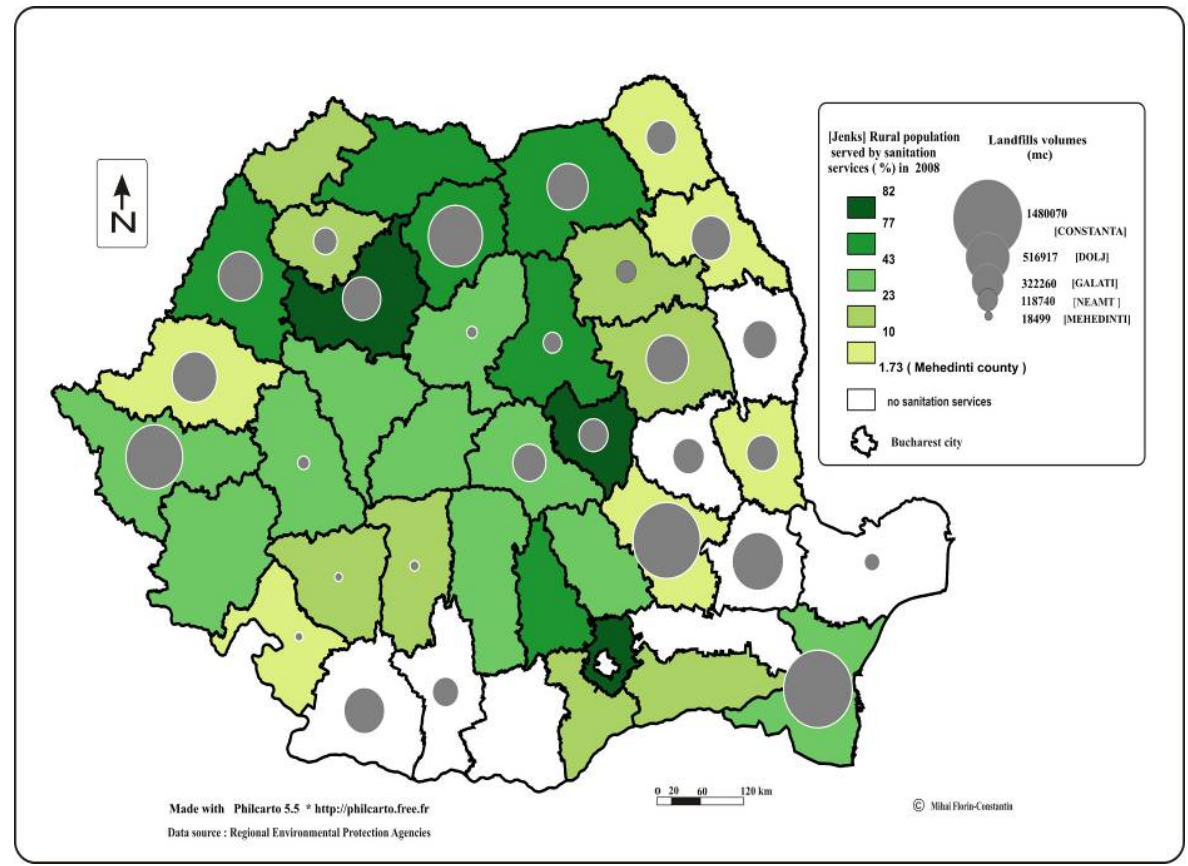

Fig. 5. Geographical distribution of landfills volumes at county level

Furthermore, some counties did not report data on dumpsites volumes; in these circumstances, a pertinent analysis is difficult to achieve at county level. However, in the map (fig.5), we can see that dumpsites volumes are higher in plain and hills counties due to a higher density of rural population in the context of low access to sanitation services (border counties in the country). Also, large number of dumpsites which occupied significant areas may have larger volumes (Buzău, Năsăud) or not (Tulcea). The socio-economic and demographic context which varies from one county to another may influence the amount of waste generated and landfilled. In some counties with a high share of rural population served by sanitation services (Cluj, Covasna, Bihor), the landfills volumes are higher than in many other counties where sanitation services of the rural areas are limited (Vâlcea, Gorj, Neamt).

Closure and rehabilitation of rural landfills have been a real challenge for local authorities, the main measures of rehabilitation being soil cover and 
compaction of the dumpsites. Following the closure of these sites, local authorities are obliged to collect the waste generated (by public or private services) and to provide transport to the nearest urban landfill.

Fulfilling these obligations depends on the responsibility of local authorities; field observations have found several malfunctions in this regard (Apostol and Mihai, 2011; Lămăşanu and Mihai, 2011).Mixed waste collection is done door to door in bags or bins and other localities have waste collection points. The locals are required to pay an annual or monthly fee (per capita or family) for waste collection services services, the amount of fees varying from case to case.

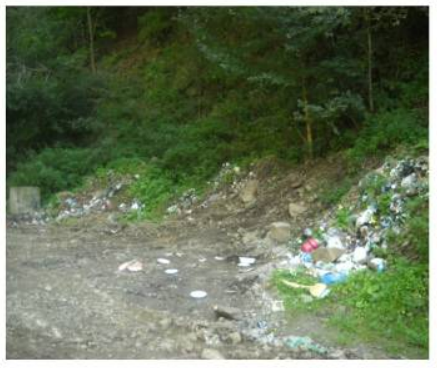

Closed dumpsite (soil covered) near Râmeți gorges, Alba county,Sept.2011

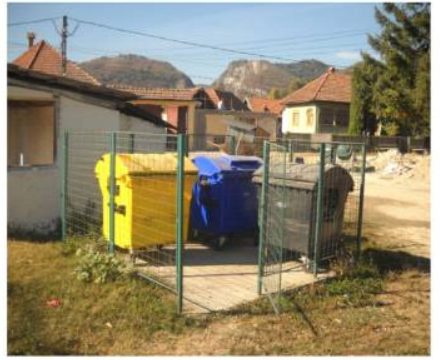

Selective waste collection point, Polovragi village,Gorj county,Sept.2011

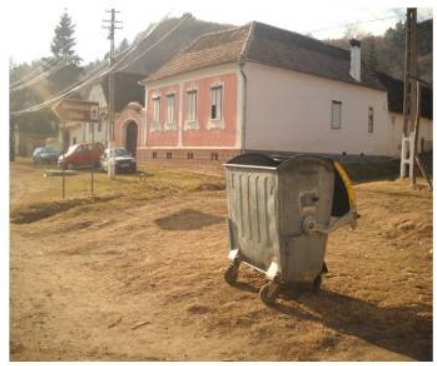

Container-mixed collection, Copşa Mare village,Sibiu county,Dec.2011

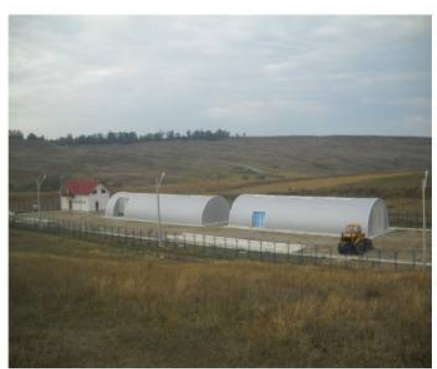

Sorting facility in construction,Bâra village, Neamt county,Sept.2009

Fig. 6 - Rural dumpsite vs. waste management facilities in rural areas

The cost of waste management is higher due to the transport of waste collected to urban landfills. EU and Government funds (PHARE and SOP-ENV) improved waste management infrastructure in some rural areas by introducing 
selective waste collection points, building transfer stations equipped with waste sorting and composting facilities (see.Fig.6)

\section{Conclusions}

The low share of rural population with access to waste collection services in 2008 reflects the geographical distribution of statistical data concerning rural dumpsites counted by the authorities in 2009 (deadline for closure and rehabilitation July 16). In addition, demographic factors, geographical and socioeconomic context influence the disparities between Romanian counties.

Waste generated and uncollected from rural areas have been disposed in improper dumpsites polluting the local environment; the rural areas in northeastern, southeastern and southern Romania are currently the most vulnerable to illegal dumping. Waste dumping is still an option for those rural localities that have limited access to sanitation services or poor waste management facilities.

However, waste management plans stipulate the implementation of integrated waste management systems which will serve rural areas of each county.

\section{Acknowledgements}

This work was supported by the European Social Fund in Romania, under the responsibility of the Managing Authority for the Sectoral Operational Programme for Human Resources Development 2007-2013 [grant POSDRU/CPP 107/DMI 1.5/S/78342].

\section{References:}

Apostol, L., Mihai, F.-C., (2011). The process of closing down rural landfills Case study: Neamț County, Present Environment and Sustainable Development, 5 (2), 167- 174

Chowdhury M., (2009), Searching quality data for municipal solid waste planning, Waste Management, 29, 2240-2247,

Lămaşanu Andreea, Mihai F.C., 2012, The illegal dumping of waste in forest areas. Evidence from rural territory. Proceedings of International Conference-Integrated Management of Environmental Resources,Suceava,Romania, November 4-6th 2011, 46-50

Mazzanti, M., Zoboli, R., (2008),Waste generation, waste disposal and policy effectiveness. Evidence on decoupling from the European Union, Resources, Conservation and Recycling, 52, 1221-1234

Mihai F.-C. Apostol,L.,(2012),Disparities in municipal waste management across EU-27. A geographical approach, Present Environement and Sustainable Development, 6 (1), $169-180$

Mihai, F.-C., Apostol,L., Ghiurca A.A, Lămăşanu A.,Bănică A.,(2012),Geographical distribution of rural dumpsites in North-East Region from Romania,Conference Proceedings of $12^{\text {th }}$ International Multidisciplinary Scientific GeoConference SGEM 2012,17-23 June 2012,Albena,Bulgaria, ,vol 5,447-452, 
Nancu, Daniela, Persu, Mihaela, Damian, Nicoleta (2011) ,The evolutions and territorial distribution of rural population in Romania at the beginning of the $21^{\text {st }}$ century, Forum geografic. Studii şi cercetări de geografie şi protecția mediului, 10, 2, 220 228,

Passarini, F., Vassura, I., Monti, F., Morselli. L., Villani, B., (2011),Indicators of waste management efficiency related to different territorial conditions, Waste Management, 31, pp. 785-792 